International Journal of Business Management and Economic Review

Vol. 3, No. 01; 2020

ISSN: 2581-4664

\title{
THE EFFECT OF KNOWLEDGE SHARING AND MOTIVATION ON INDIVIDUAL COMPETENCY AND ITS IMPACT ON EMPLOYEE PERFORMANCE OF PT. BANK NEGARA INDONESIA (PERSERO) TBK. LHOKSEUMAWE BRANCH
}

\author{
Muhammad Aulia, Said Musnadi and Faisal \\ Department of Management, Universitas Syiah Kuala, Indonesia \\ http://doi.org/10.35409/IJBMER.2020.3139
}

\begin{abstract}
This study is to test The Effect of Knowledge Sharing and Motivation on Individual Competency and Employee Performance. The object of this research is at PT Bank Negara Indonesia (Persero) TbkLhokseumawe Branch and its all employees are the respondents. The population is 150 people. the sample also amounted to 150 respondents that is taken by census method, which is the number of sample is as same as population. The data is analyzed using structural equation modeling (SEM) analysis with the AMOS software. The test is in the form of causality test. The result describes that knowledge sharing effects employee performance significantly, motivation effects employee performance significantly, knowledge sharing effects individual competence significantly, motivation effects individual competence significantly, individual competence effects employee performance significantly, knowledge sharing has an indirect effect on employee performance through the individual competence, and motivation has an indirect effect on employee performance through individual competence of employees of PT Bank Negara Indonesia (Persero) TbkLhokseumawe Branch. This model contributes to the realm of science that enrich the causality theories especially in management and social science field. This also can be a reference for the next research. The originality is in the integration of previous models, and uses SEM as a statistical approach. The limitation lies in the amount of variables and object.
\end{abstract}

Keyword: Knowledge Sharing, Motivation, Individual Competence, Employee Performance.

\section{INTRODUCTION}

The emergence of knowledge-based economics, makes organizations take a knowledge management approach and abandon the old approach or traditional approach (Trivellas, Akrivouli, Tsifora, \& Tsoutsa, 2015). Given that knowledge sharing involves the activities of employees to be able to share with others about knowledge or exchange information between coworkers in the organization.

To win competition between companies, there are several challenges that must be addressed, namely the management of intellectual assets, adaptation, market control and technology, innovation and collaboration. These challenges drive the need for the application of 


\section{International Journal of Business Management and Economic Review}

Vol. 3, No. 01; 2020

ISSN: 2581-4664

knowledge management (KM). Collaboration is important for companies that want to stay ahead in the environment of competitive business. Competitive advantage can only be achieved if the power managed and maintained is the basis of the individual's knowledge source. As also stated by (Salzer-Mörling \& Yakhlef, 1999) cited by (Andrawina, Govindaraju, Samadhi, \& I., 2008), that which will determine the success of the company is the competence of the organization or company in managing company assets.(Trivellas et al., 2015) stated that knowledge sharing can increase and sharpen knowledge and competition, which are both implicit and explicit. It can be disseminated and implemented as with a working team,solve problems, communicate interpersonally, create creativity new ideas and prioritize things.

Based on the above explanation, competence becomes a measuring tool in identifying behaviors that affect the performance of organizational members. Competence and behavior are two variables that influence positively. Competence Research that is often done by (Hidayat et al., 2008) in decades showed that competency influences individual performance.

By applying knowledge management, PT Bank Negara Indonesia (Persero) TbkLhokseumawe Branch applies knowledge sharing between supervisors and employees. Related to the research of (Sáenz, Aramburu, \& Rivera, 2009), knowledge creation or change is the main key as the success of knowledge sharing in organizations. Good performance, apart from being determined by a good system, also determined by members or parties in the organization. The Human Resources management system is then measured in collecting knowledge and knowledge donating.

In practice knowledge sharing can be a guide in managing the company's valuable assets. According to HRD manager of PT Bank Negara Indonesia (Persero) TbkLhokseumawe Branch, employee performance is felt to be lacking, leading to a lot of competition in this industry.

Management should look for solutions and develop knowledge sharing behavior. An example of a knowledge sharing behavior at PT Bank Negara Indonesia (Persero) TbkLhokseumawe Branch can be done formally or informally. Formally in the form of sharing rules, sharing information, sharing about new product training, seminars and workshops or national meetings involving all supervisors and employees. In addition, informally it can be in the form of an email or company mailing list, division briefings or instructions from superiors to employees.

Regarding the background of the problem above, the researcher felt interested in researching the Determination of Knowledge Sharing and motivation on individual competencies and Employee Performance at PT Bank Negara Indonesia (Persero) TbkLhokseumawe Branch.

\section{LITERATURE STUDY Employee performance}

Performance is the implementation of the results of planning processes compiled and carried out by human resources who have competence and motivation or interests (Wibowo, 2016). Performance is a measuring tool regarding the achievement and implementation of the level of a policy or activity to realize the goals and objectives, vision and mission of an organization that has been planned and strategically planned by an organization. Furthermore, performance is also related to job satisfaction (Moeheriono, 2012).

(Dharma, 2010) stated performance is the process of determining what is a goal to be 


\section{International Journal of Business Management and Economic Review}

Vol. 3, No. 01; 2020

ISSN: 2581-4664

achieved and how to achieve goals within a predetermined period of time, both short and long term. Then the understanding of performance according to (Mangkunegara, 2010)is the result that can be assessed in terms of quality and quantity in carrying out their duties. The definition of performance according to Prawirosentono is the result of the achievement of a person or group of organizations and is related to responsibility in efforts to achieve organizational goals. Organizational performance is good if one's performance is good (Fachreza, Musnadi, \& Shabri, 2018).

\section{Individual Competence}

(Wibowo, 2016) definedthat competence literally and etymologically is the ability, skill and expertise of someone working on a task with knowledge, skills and work attitudes. Good competence shows the work of a professional. Competence relates to behavior in carrying out work (Mangkunegara, 2010). (Kurniadi, Achsani, \& Sasongko, 2013) stated that there are two competency factors, namely: (1) Physical abilities that consist of biological characteristics and strength, (2) Intellectual abilities related to the mental.

According to Wibowo, to achieve organizational success, it takes the soul of workers, leadership and work discipline which ultimately form a high work culture and achieve work performance in the process of selecting human resources, management and so on (Rafiie, Azis, \& Idris, 2018). As a result of liberalization in the economic field, human resources play an important role for the company along with the intense competition.

\section{Motivation}

According to (Mathis, 2006)motivation is a person's desire to take action. Whereas (Zainal, 2015) gave an understanding that motivation is a series of values and attitudes of a person. Motivation is an effort to do something that is accompanied by the ability to achieve organizational goals (Robbins \& Judge, 2014). Motivation is a psychological factor that directs an individual's interest in job responsibilities (Masrukhin \& Waridin, 2006). While (Hasibuan, 2007) argued that motivation is a matter of supporting human behavior in order to want to work enthusiastically and actively in order to achieve organizational success.Motivation with processes internally is what causes an enthusiastic attitude that encourages the individual's desire to achieve certain goals (Fachreza et al., 2018). Thus it describes that motivation is an activity that moves or encourages human behavior so as to create passion or desire to work in work as an effort to achieve goals.

\section{Knowledge Sharing}

Knowledge Sharing is an individual process of exchanging knowledge (Vries, Hooff, \& Ridder, 2006). These definitions indicate that every behavior and process of knowledge exchange consists of knowledge collecting and bringing (knowledge donating). Knowledge Collecting is a consultation of one individual with another individual regarding the capital of knowledge possessed, while Knowledge Donating is the behavior of connecting intellectual capital someone has to other people.

Knowledge management is supported by elements of People, Technology and Process (Bhatt, 2000). The element bases itself on individual abilities, motivation, up to environmental and cultural development. These elements occur in daily work activities such as learning. The 


\section{International Journal of Business Management and Economic Review}

Vol. 3, No. 01; 2020

ISSN: 2581-4664

next element focuses on providing facilities or infrastructure for employees. From that three elements, People is the most essential element of knowledge management. This is caused by the behavior of employees to utilize learning and develop the knowledge provided by the organization, in order to create conducive work environment.

Research Hypothesis

From the discussion above, authors formulate the research model and hypothesis as follows.

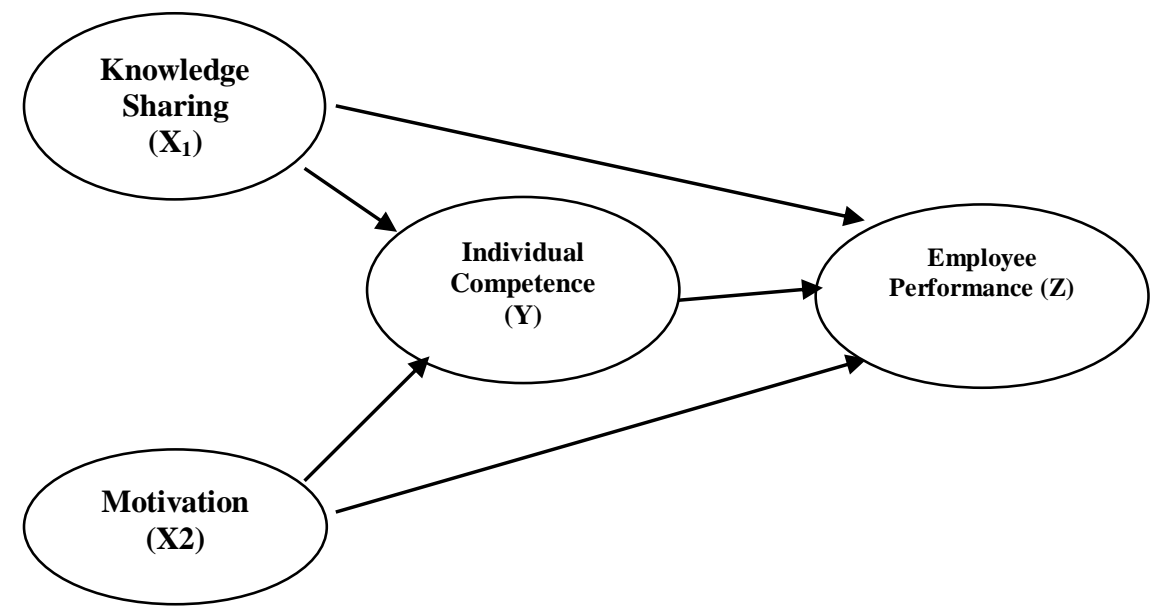

Figure 1. Research Model

H1 : knowledge sharing effectsemployee performance significantly,

$\mathrm{H} 2$ : motivationeffectsemployee performance significantly,

H3 : knowledge sharing effectsindividual competence significantly,

$\mathrm{H} 4$ : motivation effects individual competence significantly,

H5 : individual competence effects employee performance significantly,

H6 : knowledge sharing has an indirect effect on employee performance through the individual competence, and

$\mathrm{H} 7$ : motivation has an indirect effect on employee performance through individual competence..

\section{RESEARCH METHOD}

The object of this research is at PT Bank Negara Indonesia (Persero) TbkLhokseumawe Branch and its all employees are the respondents. The population is 150 people. Samples are part of the characteristics of a number of populations According to (Sugiyono, 2008). According to (Arikunto, 2014), if the subject is small, which is less than 100, whereas if the subject is large, which is more than 100 , then determining the number of samples can start between $10 \%-15 \%$ or $20 \%-25 \%$ or more. According to (Indriantoro \& Supomo, 2011), census is the whole of the population that makes attention that describes something that is real or empirical. So that the sample in this study amounted to 150 employees of PT Bank Negara Indonesia (Persero) TbkLhokseumawe Branchtaken by census method. 


\section{International Journal of Business Management and Economic Review}

Vol. 3, No. 01; 2020

ISSN: 2581-4664

The data analysis technique of this research is quantitative analysis using the Structural Equation Modeling (SEM) with AMOS software. The SEM is a part of the relationship that is built between the dependent variable (endogenous) and the independent variable (exogenous). These factors are built from several indicators that are measured directly (Latan \& Ghozali, 2012).The advantages in using the SEM model is the ability of the program to analyze all research indicators. Latent variables are variables that are not observed with concepts being approximated by variables that are observed and obtained by respondents through tests, surveys, observations (data collection methods) and often called variables listed in the model (Latan \& Ghozali, 2012). For the indirect effect, the test uses Sobel test to see the probability value.

\section{RESULT}

\section{H1 is accepted : The Effect of Knowledge Sharing on Employee Performance}

Based on the results of the research, it is proven that knowledge sharing has a significant influence on employee performance, that is shown bythe probability value generated from the model is $0.030(<0.05)$. This means that the better knowledge sharing, the better the performance of employees at PT Bank Negara Indonesia (Persero) TbkLhokseumawe Branch.

\section{H2 is accepted : The Effect of Motivation on Employee Performance}

The results of the study prove that motivation has a significant influence on employee performance, that is shown bythe probability value generated from the model is $0.033(<0.05)$. This describes that the better the motivation, the better the performance of employees at PT Bank Negara Indonesia (Persero) Tbk Lhokseumawe Branch.

\section{H3 is accepted : Effects of Knowledge Sharing on Individual Competence}

Based on the test result using SEM through the Amos program, it proves that knowledge sharing has an influence on individual competence, that is shown bythe probability value generated from the model is $0.023(<0.05)$. This figures that the better knowledge sharing, the better the individual competence of employees at PT Bank Negara Indonesia (Persero) Tbk Lhokseumawe Branch.

\section{H4 is accepted : The Effect of Motivation on Individual Competence}

The result proves that motivation has an influence on individual competence, that is shown by the probability value generated from the model is $0.014(<0.05)$. This means that the better the motivation, the better the individual competence of employees at PT Bank Negara Indonesia (Persero) Tbk Lhokseumawe Branch.

\section{H5 is accepted : The Effect of Individual Competence on Employee Performance}

Next is the result proves that individual competencehas a significant influence on employee performance, that is shown bythe probability value generated from the model is 0.006 $(<0.05)$. This means that the better the individual competence of employees, the better the performance of employees of PT Bank Negara Indonesia (Persero) Tbk Lhokseumawe Branch.

H6 is accepted : Effect of Knowledge Sharing on Employee Performance Through Individual Competence 


\section{International Journal of Business Management and Economic Review}

Vol. 3, No. 01; 2020

ISSN: 2581-4664

Based on the result, it is proven that individual competence mediates the effect of knowledge sharing on employee performance, that is shown bythe probability value generated from the Sobel Test is $0.013(<0.05)$. So this mediation is called Partial Mediation.

\section{H7 is accepted : The Effect of Motivation on Performance Employees Through Individual Competence}

Based on the resultproves that individual competence also mediates the effect of motivation on employee performance, that is shown bythe probability value generated from the Sobel test is $0.009(<0.05)$. So this mediation is called Partial Mediation.

\section{CONCLUSION}

The result describes that knowledge sharing effectsemployee performance significantly, motivationeffectsemployee performance significantly, knowledge sharing effectsindividual competence significantly, motivation effects individual competence significantly, individual competence effects employee performance significantly, knowledge sharing has an indirect effect on employee performance through the individual competence, and motivation has an indirect effect on employee performance through individual competence of employees of PT Bank Negara Indonesia (Persero) Tbk Lhokseumawe Branch. This model contributes to the realm of science that enrich the causality theories especially in management and social science field. This also can be a reference for the next research. The originality is in the integration of previous models, and uses SEM as a statistical approach. The limitation lies in the amount of variables and object.

This also has a managerial implication to leaders who lead the organization related. PT Bank Negara Indonesia (Persero) TbkLhokseumawe Branchis recommended to focus more on motivation variables, because the result of this study indicatse that motivation has the greatest influence on employee performance. In general, motivation gives a positive influence on Employee Performance at BNI Lhokseumawe Branch Office, it is recommended that companies can create an atmosphere of togetherness so that employees can have a close relationship between employees, and also by providing challenging task assignments to employees so that it will improve employee performance. So thus by improving motivation will provide a large contribution in order to improve employee performance.

PT Bank Negara Indonesia (Persero) TbkLhokseumawe Branchis advised to pay attention Knowledge Sharing variable, should be for employees who get new ideas to more often share with other employee colleagues, and also suggest to more often share knowledge about new things to other employee colleagues. Thus knowledge sharing can improve the performance of employees of PT Bank Negara Indonesia (Persero) TbkLhokseumawe Branch.

Regarding individual competencies in the PT Bank Negara Indonesia (Persero) TbkLhokseumawe Branch must be a special concern of the leader, especially with regard to the pleasure of learning new things related to work or not, so that with increasing employee individual competency, employee performance will also increase. Then related to employee work stress in relation to organizational commitment, the thing that needs to be considered is that employees must have service to their organization even though it is contrary to family service. And,to improve employee performance, the factors that need attention are employees are expected to be able to do the work accurately and thoroughly, and also employees are expected 


\section{International Journal of Business Management and Economic Review}

Vol. 3, No. 01; 2020

ISSN: 2581-4664

to be able to finish the job on time.

\section{REFERENCES}

Andrawina, L., Govindaraju, R., Samadhi, T. A., \& I., S. (2008). Absorptive capacity moderates the relationship between knowledge sharing capability and innovation capability. In the Proceedings of the 2008 IEEE International Conference on Industrial Engineering and Engineering Management, 944-948. https://doi.org/DOI: 10.1109/IEEM.2008.4738009

Arikunto, S. (2014). Prosedur Penelitian suatu Pendekatan Praktik. Jakarta: Renika Cipta.

Bhatt, D. (2000). EFQM Excellence Model and Knowledge Management Implications.

Dharma, S. (2010). Manajemen Kinerja: Falsafah Teori Dan Penerapannya. Yogyakarta: Pustaka Pelajar.

Fachreza, Musnadi, S., \& Shabri, M. (2018). Pengaruh Motivasi Kerja, Lingkungan Kerja, dan Budaya Organisasi Terhadap Kinerja Karyawan dan Dampaknya Pada Kinerja Bank Aceh Syariah Di Kota Banda Aceh. Jurnal Magister Manajemen, 1(1).

Hasibuan, M. S. P. (2007). Manajemen Sumber Daya Manusia Perusahaan. Bandung, PT. Bumi Aksa.

Hidayat, D. R., Elmubarok, Z., Johnson, A. S., Simamora, R., Zahro, \& Ahmad. (2008). Membumikan Pendidikan Nilai Mengumpulkan yang Terserak, Menyambung yang Terputus, dan Menyatukan yang Tercerai. Jakarta: AlFABETA.

Indriantoro, N., \& Supomo, B. (2011). Metodologi Penelitian Bisnis Untuk Akuntansi Dan Manajemen. Yogyakarta: BPFE.

Kurniadi, A., Achsani, N. A., \& Sasongko, H. (2013). Kinerja Keuangan Berbasis Penciptaan Nilai, Faktor Makroekonomi dan Pengaruhnya Terhadap Return Saham Sektor Pertanian. Jurnal Akuntansi Dan Keuangan, 15(2). https://doi.org/https://doi.org/10.9744/jak.15.2.6374

Latan, H., \& Ghozali, I. (2012). Partial Least Square: Konsep, Teknik, dan Aplikasi SmartPLS 2.0 M3. Semarang: Badan Penerbit Universitas Diponogero.

Mangkunegara, A. A. A. P. (2010). Evaluasi Kinerja SDM (2nd ed.). Bandung: Refika Aditama. Masrukhin, \& Waridin. (2006). Pengaruh Motivasi Kerja, Kepuasan Kerja, Budaya Organisasi Dan Kepemimpinan Terhadap Kinerja Pegawai. Jurnal Ekonomi Dan Bisnis, 7(2), 197-209. Mathis, J. (2006). Human Resource Management (10th ed.). Jakarta: Salemba Empat.

Moeheriono. (2012). Pengukuran Kinerja Berbasis Kompetensi (Revision). Rajawali Pers, Ekonomi/Manajemen.

Rafiie, D. S., Azis, N., \& Idris, S. (2018). Pengaruh Kompetensi, Gaya Kepemimpinan, Budaya Kerja, dan Lingkungan Kerja Terhadap Kepuasan Kerja Pegawai dan Dampaknya Terhadap Kinerja Pegawai Kantor Kementerian Agama Kabupaten Aceh Barat. Jurnal Magister Manajemen, 2(1), 36-45.

Robbins, S. P., \& Judge, T. A. (2014). Buku Perilaku Organisasi Buku 2 (Edisi ke-1; alih bahasa D. Angelica, Ed.). Salemba Empat.

Sáenz, J., Aramburu, N., \& Rivera, O. (2009). Knowledge sharing and innovation performance: A comparison between high-tech and low-tech companies. Journal of Intellectual Capital, 10(1), 22-36. https://doi.org/https://doi.org/10.1108/14691930910922879 
Vol. 3, No. 01; 2020

ISSN: 2581-4664

Salzer-Mörling, M., \& Yakhlef, A. (1999). The Intellectual Capital: Managing by Measure. The 1999 Critical Perspective on Accounting Conference. New York: Stockholm University.

Sugiyono. (2008). Metode Penelitian Bisnis. Bandung: Alfabeta.

Trivellas, P., Akrivouli, Z., Tsifora, E., \& Tsoutsa, P. (2015). The Impact of Knowledge Sharing Culture on Job Satisfaction in Accounting Firms. The Mediating Effect of General Competencies. Procedia Economics and Finance, 19(15), 238-247. https://doi.org/10.1016/s2212-5671(15)00025-8

Vries, R. E. de, Hooff, B. Van den, \& Ridder, J. A. de. (2006). Explaining Knowledge Sharing The Role of Team Communication Styles, Job Satisfaction, and Performance Beliefs. Communication Research, 33(2). https://doi.org/DOI: 10.1177/0093650205285366

Wibowo. (2016). Manajemen Kinerja (kelima). Jakarta: PT. Rajagrafindo Persada.

Zainal, V. R. (2015). Manajemen Sumber Daya Manusia Untuk Perusahaan: Dari Teori ke Praktik. In Jakarta: PT. Raja Grafindo Persadi (Edisi Keti). Depok: PT. Rajagrafindo Persada. 